JOURNAL OF APPLIED SMART ELECTRICAL
NETWORK AND SYSTEMS (JASENS)
ISAS

\title{
Penanganan Lonjakan Vibrasi pada Rotor Elektrik Turbin di PLTU Gresik
}

\author{
Abdul Ghofar Romdhon ${ }^{1}$. Mohammad ilham² Rini Puji Astutik ${ }^{3}$. Denny Irawan ${ }^{4}$ \\ 1,2,3,4) Jurusan Teknik Elektro, Universitas Muhammadiyah Gresik \\ 1abdulghofar_170603@umg.ac.id.2ilham_170603@umg.ac.id 3astutik_rpa@umg.ac.id 4den2mas@umg.ac.id
}

\begin{abstract}
This analysis will discuss how to handle vibrations in the Turbine Rotor. The measuring instrument used is Vibration Analysis test with Prov. 2140 type which measured amplitude, time and frequency domain of vibration signal. The results obtained in this study, firstly, the measurement vibration of rotor at PT PJB Gresik found the highest amplitude of vibration was $59,6 \mu \mathrm{m}$ at $3000 \mathrm{rpm}$. In this condition, the rotor is in very good condition as per standard vibration in ISO 7919-2 stated $80 \mu \mathrm{m}$ at $3000 \mathrm{rpm}$. However in the next measurement, there is an dramatically increase of amplitude in each vibration measurement. The top amplitude of vibration reached at $115 \mu \mathrm{m}$ at $3000 \mathrm{rpm}$ and shown a symtom of damage on the rotor as a result of vibration. In solving the problem this time we use the method Root couse analysis (RCA). The results of this research found that there was a short turn to turn on the rotor windings and the closed slot liner holes that caused electric vibrations and needed to be repaired to eliminate vibration disturbances. After repairing the vibration, it decreased which initially $115 \mu \mathrm{m}$ to $33.5 \mu \mathrm{m}$ at $3000 \mathrm{Rpm}$, it is still on the range of the permitted safe zone of ISO standard 7919-2.
\end{abstract}

Keywords: Vibration, Handling of Rotor vibration disturbances.

\begin{abstract}
Abstrak
Analisa ini akan membahas cara menangani getaran pada Rotor Turbin. Alat ukur yang digunakan adalah Analisis Getaran dengan Prov. Tipe 2140 yang mengukur domain amplitudo, waktu dan frekuensi sinyal getaran. Hasil yang diperoleh Pada penelitian ini, pertama pengukuran getaran rotor di PT PJB Gresik didapatkan amplitudo getaran tertinggi yaitu 59,6 $\mu \mathrm{m}$ pada $3000 \mathrm{rpm}$. Pada kondisi ini, kondisi rotor sangat baik sesuai standar getaran pada ISO 7919-2 yang menyatakan $80 \mu \mathrm{m}$ pada $3000 \mathrm{rpm}$. Namun pada pengukuran selanjutnya, terjadi peningkatan amplitudo yang dramatis. Amplitudo puncak getaran mencapai $115 \mu \mathrm{m}$ pada $3000 \mathrm{rpm}$ dan menunjukkan kerusakan pada rotor akibat getaran. Dalam pemecahan masalah ini kami menggunakan metode "Root Couse Analysis". Root couse analysis (RCA) merupakan metode pencarian masalah dengan cara memilah sebab dan akibat suatu masalah atau metode FMEA. Hasil dari penelitian kali di temukan adanya short turn to turn pada bilitan rotor dan lubang slot liner yang tertutup sehingga menyebabkan vibrasi elektrik dan perlu dilakukan repair untuk menghilangkan ganguan vibrasi.setelah dilakukan repair, vibrasi menurun yang awalnya $115 \mu \mathrm{m}$ menjadi $33.5 \mu \mathrm{m}$ pada Rpm 3000 masuk pada standart zona aman yang di izinkan ISO 7919-2.
\end{abstract}

Kata Kunci : Vibrasi, Penanganan Ganguan vibrasi Rotor.

Diterima Redaksi : 01-12-2020 | Selesai Revisi : 25-12-2020 | Diterbitkan Online : 31-12-2020

\section{Pendahuluan}

Konsumsi energi listrik di Indonesia dari tahun ke tahun semakin meningkat seiring dengan pertumbuhan penduduk yang semakin bertambah. Peningkatan produktivitas pembangkit merupakan salah satu Bagaimanapun, pemeliharaan yang tidak layak/semestinya permasalahan kunci suatu pembangkit untuk tetap dan tidak handalnya peralatan pembangkit sering kompetitif di era globalisasi, dan hal yang paling membatasi produktivitas unit pembangkit. menyatakan mempengaruhi produktivitas pembangkit adalah bahwa sepertiga dari total biaya pemeliharaan dihabiskan Availability (ketersediaan) dan Reliability (Keandalan). tanpa ada manfaatnya yang dikarenakan oleh perencanaan 
yang tidak baik,overtime (lembur), tidak maksimalnya penggunaan system work order dan keterbatasan atau penyalahgunaan predictive maintenance (Pdm). Oleh karena itu, tidak diragukan lagi bahwa pemeliharaan merupakan fungsi pendukung yang mahal. Biaya pemeliharaan suatu pembangkit berkisar antara $15 \mathrm{~s} / \mathrm{d} 40$ $\%$ dari total biaya produksi. Secara teori, pemeliharaan yang baik didefinisikan sebagai pemeliharaan yang apabila pemeliharaan corrective (tidak terencana) nya sangat sedikit dan apabila sekecil dan sebisa mungkin dilaksanakan. Pemeliharaan secara terus menerus akan dan pasti menurunkan availability dan menaikkan biaya pemeliharaan dalam hal sebagai contoh biaya personil dan material/spare parts. Preventive maintenance yang paling efektif seharusnya direncanakan untuk apabila kondisi peralatan sudah melewati batas normalnya (sesuai standart manual book).[2]

Turbin uap merupakan mesin pembangkit tenaga yang bagian utamanya adalah rotor yang berputar yang dihubungkan dengan kopling ke generator listrik. Rotor terdiri dari sudu sudu yang dipasang pada poros. Vibrasi rotor turbin uap yang dapat mengakibatkan kerusakan yaitu rotor bending, rotor rubs, Short Turn to Turn pada rotor and casing misalignment dan rotor unbalance [3][4][5]. Vibrasi merupakan respon dari suatu sistem terhadap gaya yang diterima oleh mesin, baik dari dalam maupun dari luar sistem.[6][7] Gaya yang diterima oleh sistem dapat bersumber dari kegagalan atau kerusakan yang terjadi pada peralatan ataupun komponen peralatan tersebut, misalnya suatu rotor memiliki vibrasi/ getaran yang tinggi akibat rusaknya isolasi yang menyebabkan short antar lempengan (Short turn to turn) [8].

\section{Metode Penelitian}

Penelitian Vibrasi Elektric pada Rotor ini dilakukan di PT.PJB Gresik yang didasari atas terjadinya Vibrasi tinggi pada rotor sehingga dibutuhkan penanganan yang serius supaya bisa di atasi dengan efektif untuk menghemat waktu.

Vibrasi tertinggi bearing 3 pada kisaran $115 \mu \mathrm{m}$ ( Range Mvar $-40 \mathrm{~s} / \mathrm{d}$ 15),seperti pada gambar 1 .

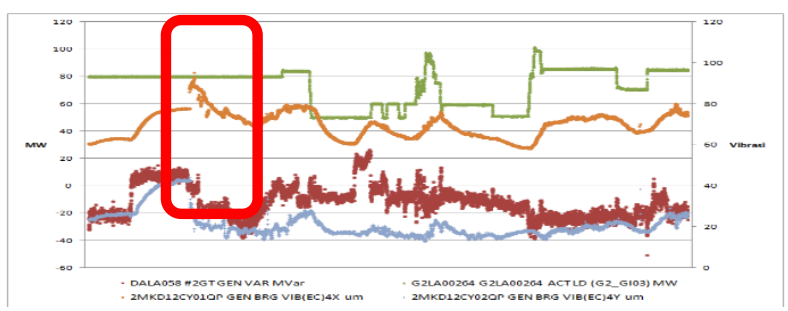

Gambar 1. Trend Vibrasi Tinggi 1.

Metode penelitian dimulai dengan studi literatur dan bisa dilihat alurnya pada gambar 2 .

studi literatur yaitu mencari informasi melalui bukubuku, jurnal, artikel, dan internet yang berhubungan dengan elemen-elemen yang dipakai dalam penelitian ini. Sumber langsung didapatkan dari hasil diskusi maupun konsultasi dengan dosen atau orang yang mempunyai kompetensi di bidang ini. Adapun literaturliteratur yang dipelajari adalah:

a. International Standard ISO10816-1 (Evaluation of machine vibration)

b. International Standart ISO7919-2 (Evaluation of machine vibration)

c. Vibration books jurnal 1-3 PLN University

d. Epri Partialdischarge jurnal 1001209

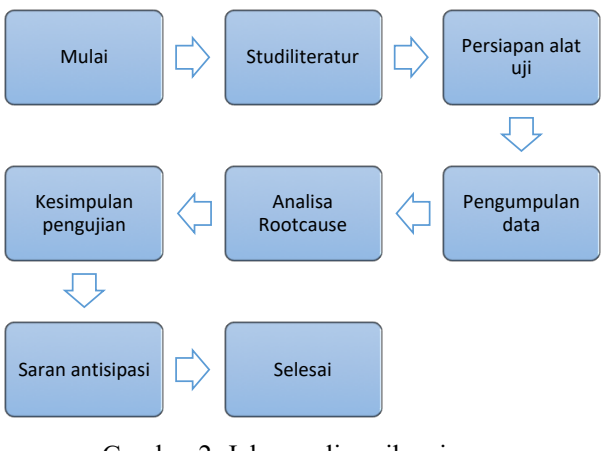

Gambar 2. Jalur analisa vibrasi

\subsection{Analisa Vibrasi}

Metode dasar dalam menganalisa vibrasi:

1. Time Wave Form, level vibrasi dipetakan pada waktu

2. Orbit, memetakan vibrasi dalam arah $\mathrm{x}$ dan $\mathrm{y}$

3. Spektrum, level vibrasi dipetakan terhadap frekuensi

Seperti pada Table 1 berikut :

Table 1 Resume metode analisa vibrasi.

\begin{tabular}{llll}
\hline Metode & Aplikasi & Keterangan & Instrument \\
\hline $\begin{array}{l}\text { Time } \\
\text { Waveform }\end{array}$ & Modulasi, & Amplitudo vs & Analog dan digital \\
Analysis & pulsa,dsb & waktu & ossiloskop,FFT analyzer \\
\hline Orbital & Shaft motion & Gerak relatif & Ossiloskop dan beberapa \\
analysis & & rotor pada & FFT anlyzer \\
& & arah XY & \\
\hline Phase & Force/motion & Beda waktu & Strobe light,analog dan \\
analysis & relationship & relatif satu & digital ossiloskop,FFT \\
& & sinyal vibrasi & analyzer \\
& & dengan sinyal & \\
& & vibrasi lainya & \\
\hline Spectrum & Langsung & Amplitudo vs & FFT analyzer \\
Analysis & menghubungkan & frekuensi & \\
& frekuensi dengan & penyebab & \\
& & kerusakan & \\
& & &
\end{tabular}

Pengukuran Vibrasi biasanya dilakukan disaat :

1. Commisioning test untuk peralatan atau equipment baru

2. Post Maintenance Test atau test setelah perbaikan

3. Tes untuk kebutuhan harian (sesuai jadwal predictive maintenance), dll 
Analisa vibrasi bertujuan untuk mengidentifikasi penyebab penyebab vibrasi pada suatu peralatan. Analysis spektrum digunakan untuk mengukur dengan lebih detil, setiap puncak yang dominan pada spektrum digunakan untuk perbandingan, baik dengan standar tertentu maupun dengan data baseline. Satu atau bahkan lebih dari satu parameter (velocity, displacement, acceleration) dapat diimplementasikan. Bearing clearance merupakan salah satu hal penting untuk dimonitor, untuk jurnal bearing rasio eksentrisitas merupakan hal penting untuk dapat mengetahui kondisi, dimana eksentrisitas adalah jarak antara pusat shaft dengan pusat jurnal bearing, sedangkan rasio eksentrisitas adalah perbandingan antara eksentrisitas yang sudah dijelaskan terhadap radial clearance. Jangan lupa untuk memasukkan beban (load) sebagai faktor yang harus dipertimbangkan dalam menganalisis kondisi [9].

\subsection{Proses Analisa Vibrasi}

1. Pengukuran Vibrasi menggunakan tranducer Vibration Analyze test type (Ams 2140), di mana data yang diperoleh masih dalam bentuk sinyal yang kompleks seperti pada gambar 3 .

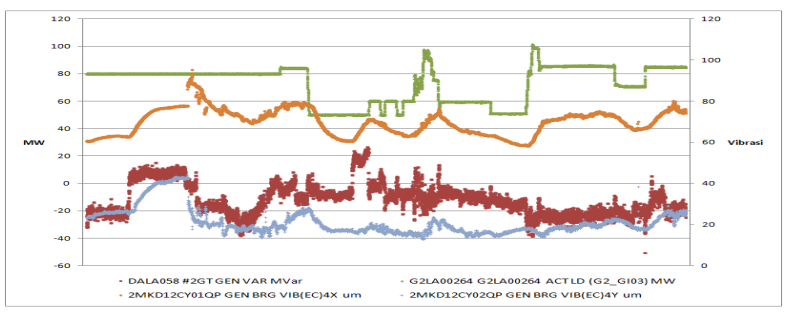

Gambar 3.Data Output trandsuser sinyal (waveform).

2. Sinyal kompleks dirubah menjadi sinyal sederhana (Spektrum) pada analyzer menggunakan proses FFT (Fast Fourier Transform) seperti gambar 4.
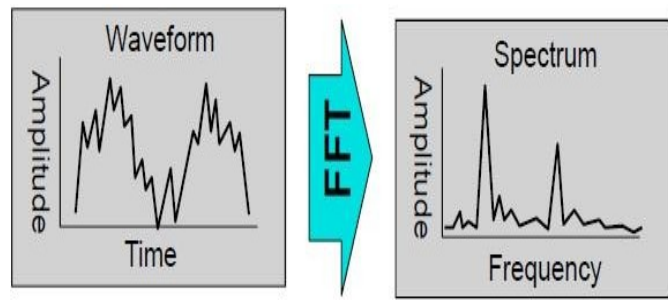

Gambar 4. Proses pemecahan sinyal menggunakan proses FFT.

Dari pengukuran vibrasi yang dilakukan, data yang diperoleh berbentuk waveform yang kompleks. Untuk menganalisa sinyal yang kompleks, diperlukan proses FFT (Fast Fourier Transform) yaitu proses pemecahan kompleks menjadi komponennya yang berupa sinyal sederhana (spektrum) seperti gambar 5 .

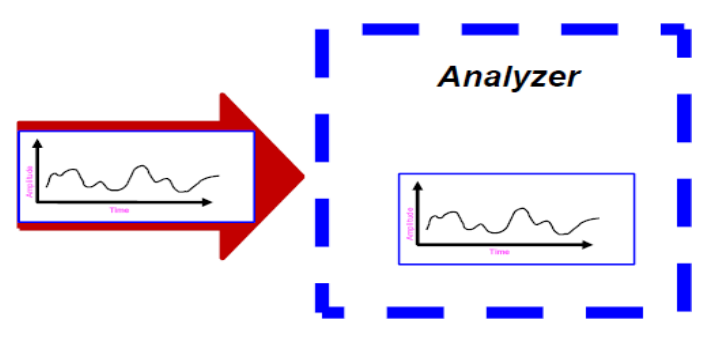

Gambar 5. Proses FFT terjadi pada analyzer

Sebuah FFT analyzer adalah sebuah computer berbasis instrumen digital. Sebuah blok data digital dalam converter analog-to-digital diproses dalam algoritma FFT untuk menghasilkan sebuah spectrum. Sebuah waveform dapat direkonstruksi dari blok data digital. Dual-channel dari FFT analyzer memungkinan untuk menampilkan sifat dan fasa dari dua sinyal yang berbeda.

FFT analyzer memiliki resolusi yang cukup tinggi tetapi masih bisa untuk menangani akurasi dari amplitudo, tergantung dari setup. Secara umum juga FFT analyzer digunakan untuk mengambil data yang steady-state, bukan yang transient. FFT analyzer memperoleh blok data pada sampling rate yang tinggi, lebih dari 200000 sample per detik, tergantung dari frekuensi tertinggi dari rentang frekuensi dari analyzer tersebut. Analyzer tersebut juga membutuhkan sinyal lengkap dari keseluruhan cycle sebelum FFT analyzer memulai mengolah data. Hal ini berarti bahwa pada frekuensi rendah(dibawah $10 \mathrm{~Hz}$ ), diperlukan pengambilan sample untuk waktu yang lama sebelum proses FFT dilakukan. Kemampuan analyzer tersebut untuk mengetahui adanya objek ketika kecepatan berubah secara cepat cukup bagus [10].

\subsection{Proses Penganalisaan data}

Setelah data yang diperoleh telah disederhanakan, maka analis vibrasi memiliki dua data sebagai bahan analisa yaitu; Waveform dan Spektrum. Waveform dan spektrum merupakan data yang sama namun memiliki cara pandang yang berbeda, dimana Waveform merupakan gelombang vibrasi membandingkan amplitud dengan waktu atau disebut juga Time Domain, sedangkan Spektrum merupakan gelombang vibrasi yang membandingkan amplitudo dengan frekuensi atau disebut juga Frequency Domain. [8] [9][10]

Wave form dan spektrum digunakan secara bersama untuk memperoleh informasi yang tepat mengenai kondisi dari suatu peralatan.

\subsection{Vibration Severity}

Vibration Severity atau level vibrasi merupakan nilai yang menggambarkan tinggi rendahnya nilai vibrasi dari suatu peralatan. Untuk menentukan kapan dan pada nilai berapa suatu peralatan perlu dilakukan perbaikan maka diperlukan suatu standar atau acuan. Ada beberapa standar yang 
dijadikan referensi atau acuan, diantaranya mengacu pada rekomendasi manufacture pada manual book atau mengacu pada standar suatu lembaga.

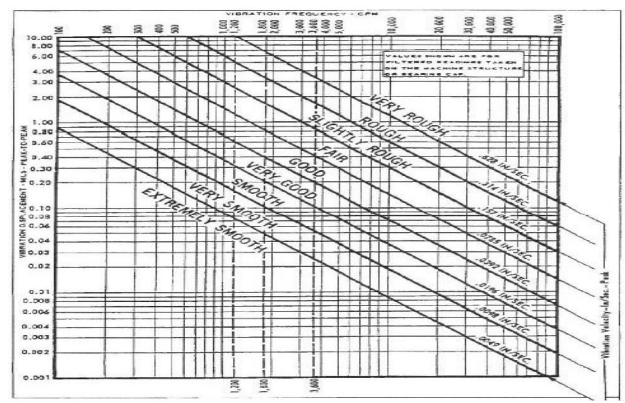

Gambar 6. IRD Standard untuk pengukuran vibrasi.

Ada beberapa lembaga yang mengeluarkan standar vibrasi suatu peralatan, diantaranya ISO (International Standart Organization) dan Canadian Government Spesification. Dalam pemilihan standar perlu diperhatikan spesifikasi dan data teknis peralatan agar sesuai dengan standar yang berlaku [11].

Untuk pengukuran vibrasi yang berbasis pada shaft (non reciprocating machine) dapat mengacu pada International Standart Organization (ISO) 7919 untuk menentukan tingkat kondisi suatu peralatan dan ISO 10816 untuk pengukuran vibrasi yang berbasis pada casing (non rotating part)[12][13] Gambar 6 -7.

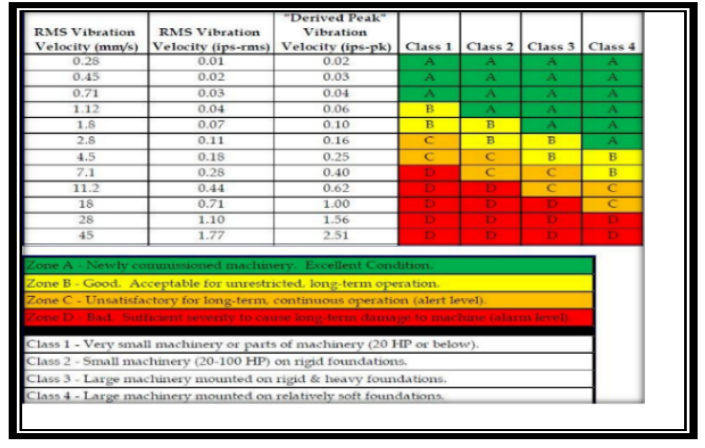

Gambar 7. Standar ISO 10816 untuk vibrasi

\subsection{Persiapan alat uji}

Pada tahap ini dilakukan persiapan alat yang di butuhkan untuk melakukan analisa vibrasi pada rotor turbin adapun alat yang dibutuhkan adalah :

\section{Vidiosscope test type $(G E 3,5 m)$}

2. Vibration Analyze test type (Ams 2140)

3. DC Resistance test dan Ac Impedan test 4. Insulation Resistance test

\begin{tabular}{lll}
\hline Speed range & $\begin{array}{l}\text { Vibration of non- } \\
\text { rotating parts }\end{array}$ & $\begin{array}{l}\text { Shaft relative and shaft } \\
\text { absolute vibration }\end{array}$ \\
(in relation to rated & & \\
speed) &
\end{tabular}

$<20 \% \quad$ n/a (see Note) $\quad 1,5 \times$ C/D boundary
Ta

\section{Repetitive Surge Osciloscope (RSO)}

\subsection{Pengumpulan Data}

1. Pengumpulan data mengunakan metode Observasi langsung di lapangan. menurut Suharsimi Arikunto Metode Observasi adalah pengamatan langsung terhadap suatu objek yang ada di lingkungan yang sedang berlangsung meliputi berbagai aktivitas perhatian terhadap kajian objek dengan menggunakan pengindraan[14].

Type rotor pada pembangkit yang di uji adalah cylindrical gambar 8 dengan Spesifikasi Table 2 .

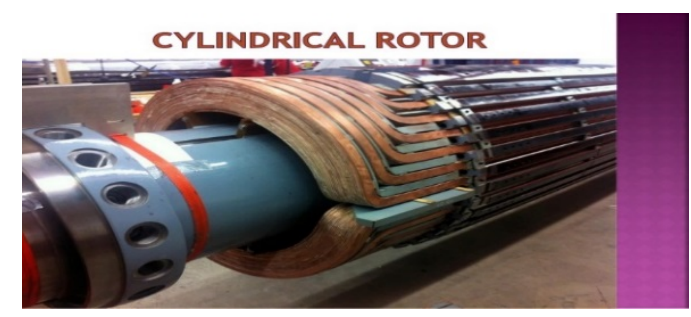

Gambar 8. Cylindrical Rotor

Table 2.Spesifikasi Rotor

\begin{tabular}{|c|c|c|c|}
\hline UNIT & GENERATOR & MERK & MITSUBISHI \\
\hline VOLTAGE & $: 20 \mathrm{KV}$ & TYPE/TAHUN & QFSN-300-2-20B \\
\hline RATED POWER & :316 MW & LOCATION & GRESIK \\
\hline POLE/RPM & $2 / 3000$ & SERIAL NO & HD191-1-12 \\
\hline
\end{tabular}

Design slot liner normal sesuai Standart Gambar 9 :

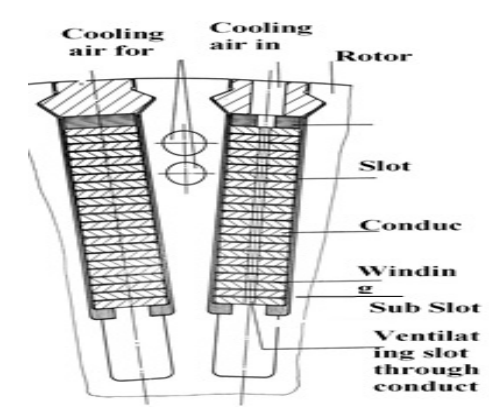

Gambar 9. Sub-slot liner normal.

Disini terlihat coling air pada Ventilasi slot liner lurus dan tidak bengkok menutupu lubang coling air sehinga udara bisa bersirkulasi unruk mendinginkan rotor.

Standart Vibrasi yang digunakan ISO 7919-2 Table 3-5:

Table 3. Nilai maximum yang di rekomendasikan pada poros rotor generator di batas zona

\begin{tabular}{|c|c|}
\hline $20 \%$ to $90 \%$ & $\begin{array}{l}1,0 \times \mathrm{C} / \mathrm{D} \text { boundary } 1,5 \times \mathrm{C} / \mathrm{D} \text { boundary } \\
\text { Journal of Applied Smart Electrical Network and Systems (JASENS) }\end{array}$ \\
\hline $0 \%$ & $1,0 \times \mathrm{C} / \mathrm{D}$ boundary \\
\hline
\end{tabular}


Zona aman nilai maximum absolut yang direkomendasikan adalah.

Table 4. Nilai maximum absolut yang di rekomendasikan pada poros rotor generator di batas zona

\begin{tabular}{|c|c|c|c|c|}
\hline \multirow[t]{3}{*}{ Zone boundary } & \multicolumn{4}{|c|}{$\begin{array}{l}\text { Shaft rotational speed } \\
\mathrm{r} / \mathrm{min}\end{array}$} \\
\hline & 1500 & 1800 & 3000 & 3600 \\
\hline & \multicolumn{4}{|c|}{$\begin{array}{l}\text { Peak-to-peak absolute displacement of shaft } \\
\mu \mathrm{m}\end{array}$} \\
\hline $\mathrm{A} / \mathrm{B}$ & 120 & 110 & 100 & 90 \\
\hline $\mathrm{B} / \mathrm{C}$ & 240 & 220 & 200 & 180 \\
\hline $\mathrm{C} / \mathrm{D}$ & 385 & 350 & 320 & 290 \\
\hline
\end{tabular}

Table 5. batas alarm selama run up, run down dan overspeed

\begin{tabular}{|c|c|c|c|c|}
\hline \multirow[t]{3}{*}{ Zone boundary } & \multicolumn{4}{|c|}{$\begin{array}{l}\text { Shaft rotational speed } \\
\mathrm{r} / \mathrm{min}\end{array}$} \\
\hline & 1500 & 1800 & 3000 & 3600 \\
\hline & \multicolumn{4}{|c|}{$\begin{array}{l}\text { Peak-to-peak relative displacement of shaft } \\
\mu \mathrm{m}\end{array}$} \\
\hline $\mathrm{A} / \mathrm{B}$ & 100 & 90 & 80 & 75 \\
\hline $\mathrm{B} / \mathrm{C}$ & 200 & 185 & 165 & 150 \\
\hline $\mathrm{C} / \mathrm{D}$ & 320 & 290 & 260 & 240 \\
\hline
\end{tabular}

NOTE : The ratio of vibration displacement to velocity is inversely proportional to frequency; hence, for measurment made on non-rotating parts, there are drawbacks in using a constant velocity criterion at speeds below $20 \%$ of rated speed. Table 5. [15][16]

Data sebelum dan saat terjadinya vibrasi yang di dapat pada tabel berwarna merah adalah saat Trip karena terjadinya vibrasi. Table 6.

Table 6. Data vibrasi yang diperoleh.

\begin{tabular}{|c|c|c|c|c|c|c|}
\hline Tag & $\begin{array}{l}\text { G2LA001 } \\
01\end{array}$ & G2LA00264 & $\begin{array}{l}\text { 2MBD11 } \\
\text { CY01QP }\end{array}$ & $\begin{array}{l}\text { 2MBD12CY } \\
01 \mathrm{QP}\end{array}$ & $\begin{array}{l}\text { 2MKD11 } \\
\text { CY01QP }\end{array}$ & $\begin{array}{l}\text { 2MKD12 } \\
\text { CY01QP }\end{array}$ \\
\hline Name & $\begin{array}{l}\text { SPEED } \\
\text { (G2_GI03 } \\
\text { ) }\end{array}$ & $\begin{array}{l}\text { ACT LD } \\
\left(\mathrm{G} 2 \_G I 03\right)\end{array}$ & $\begin{array}{l}\text { BRG } \\
\text { VIB(TR) } \\
1 \mathrm{X}\end{array}$ & $\begin{array}{l}\text { BRG } \\
\operatorname{VIB}(\mathrm{CM}) 2 \mathrm{X}\end{array}$ & $\begin{array}{l}\text { GEN } \\
\text { BRG } \\
\text { VIB(TR) } \\
3 \mathrm{X}\end{array}$ & $\begin{array}{l}\text { GEN } \\
\text { BRG } \\
\text { VIB(EC) } \\
4 \mathrm{X}\end{array}$ \\
\hline Unit & RPM & MW & um & um & um & um \\
\hline $\begin{array}{l}15 / 03 / 2020 \\
21: 10: 00\end{array}$ & 3005 & 59,4 & 24,9 & 31,5 & 48,3 & 62,3 \\
\hline $\begin{array}{l}\text { 15/03/2020 } \\
21: 11: 00\end{array}$ & 3005 & 59,4 & 45.9 & 55.3 & 67.5 & 75.2 \\
\hline $\begin{array}{l}\text { 15/03/2020 } \\
21: 12: 00\end{array}$ & 3005 & 59,6 & 83.9 & 115 & - & - \\
\hline
\end{tabular}

\subsection{Analisa Root cause}

Analisa Root Cause adalah metode pencarian masalah dengan mengurutkan pencarian gangguan di suatu objek Perencanaan analisa disini merupakan alur dari cara kerja yang digambarkan melalui gambar 12 .

Didalam flowchart tersebut dijelaskan memiliki 5 metode pengujian [17][18][19] Gambar 10.

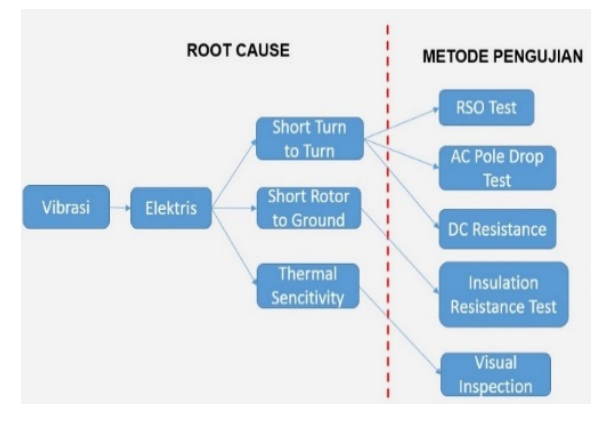

Gambar 20. Flow Chart Penelitian vibrasi

\section{Keterangan :}

1. Proses awal dilakukan dengan menentukan criteria masalah vibrasi : Elektrik.

2. Kemudian dari criteria tersebut dijabarkan lagi penyebab vibrasi elektrik.

Dari kriteria tersebut di perinci lagi dengan melakukan pengujian dengan alat untuk mendapatkan hasil yang akurat.

\section{Hasil dan Pembahasan}

Data hasil penelitian dengan mengunakan metode Root Cause yang di peroleh :

Hasil data pengujian DC Resistance test dan Ac Impedan test Gambar 11. 


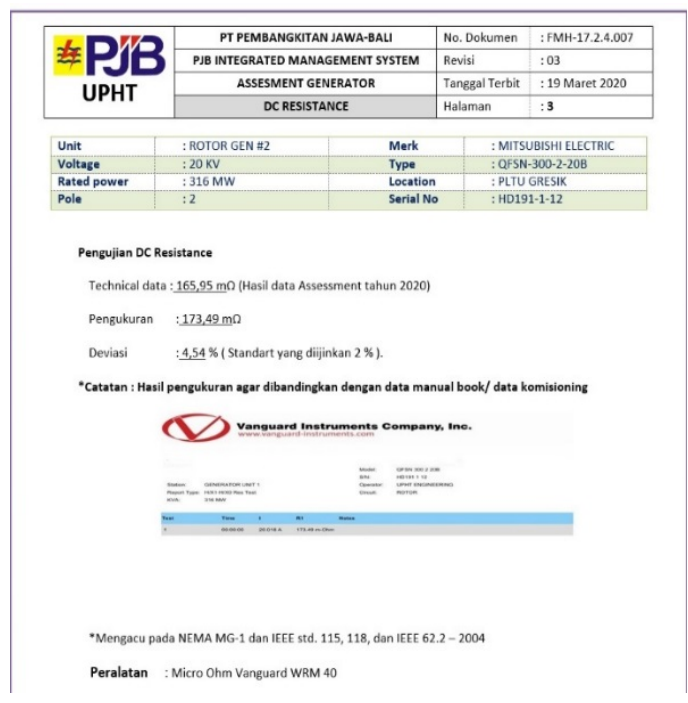

Gambar 11. Data pengujian DC resistance,Ac impedan test

Hasil data pengujian Insulation Resistance test Gambar 12:

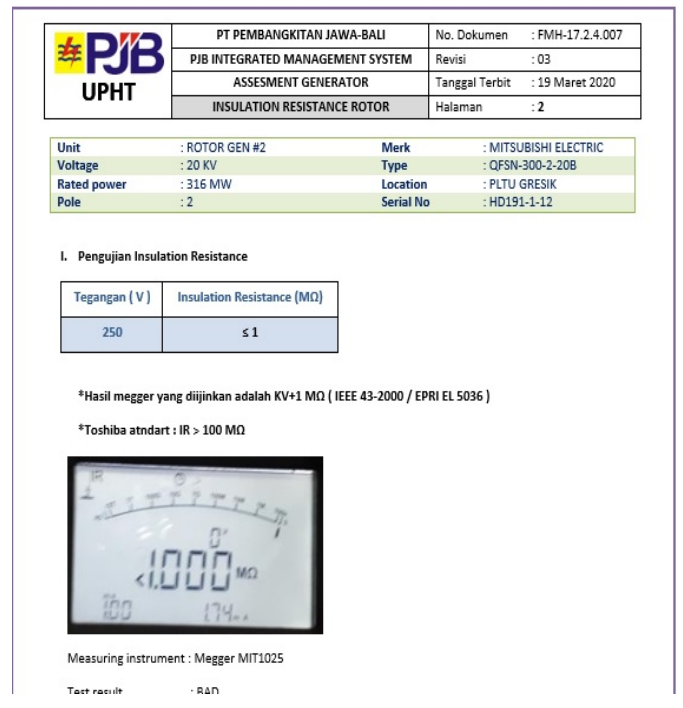

Gambar 12. Data hasil Insulation Resistance tes

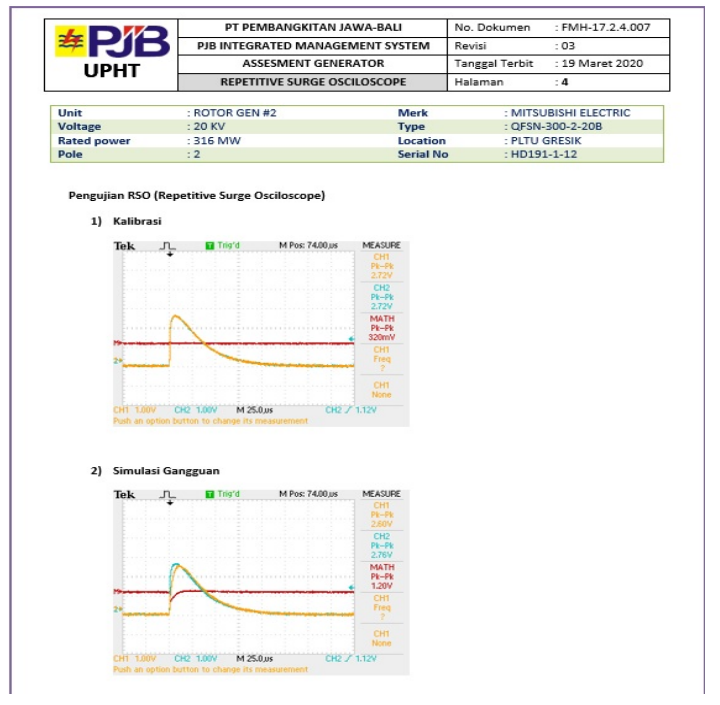

Gambar 13. Data kalibrasi RSO

Berikut pada Gambar 13. adalah data kalibrasi awal alat untuk memastikan nilai pengujian yang didapat benar dan akurat.

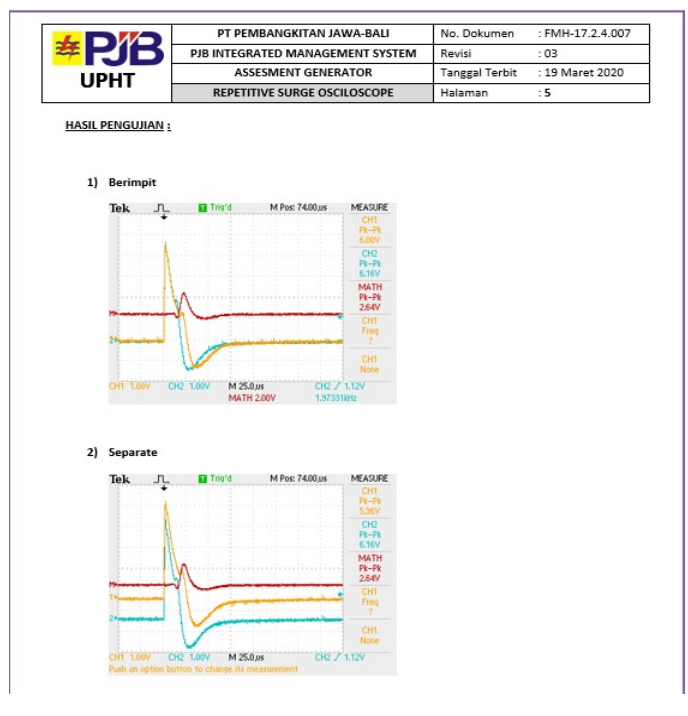

Gambar 14. Data hasil pengujian RSO

Hasil data pengujian Repetitive Surge Osciloscope Kedua gelombang sisi IN dan sisi OUT bentuknya tidak identik, sehingga dapat disimpulkan kondisi belitan rotor terjadi short turn to turn Gambar 14-15. 


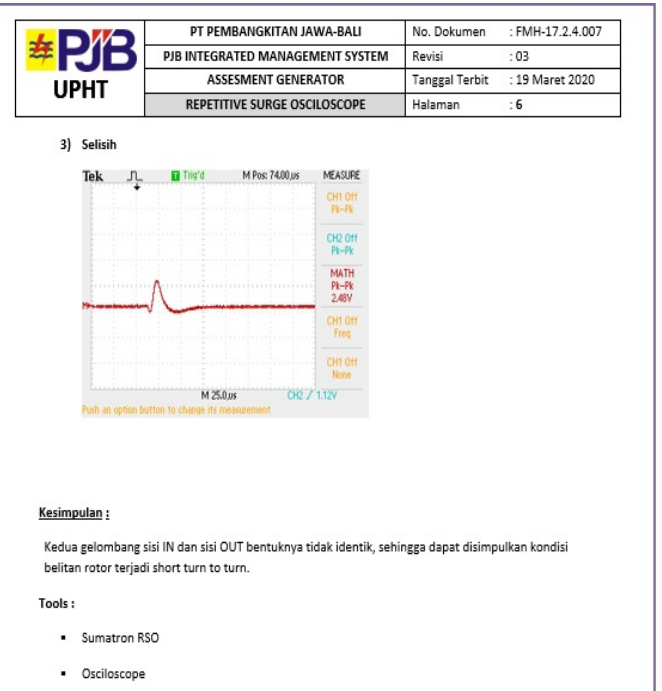

Gambar 15. Data hasil pengujian RSO 1

Dari penelitian Root couse ditemukan 2 kondisi tidak normal yang menyebabkan terjadinya Vibrasi :

1. Lubang ventilasi yang terhalang sub slot liner menyebabkan panas yang tidak merata pada setiap winding. Pemanasan ini menyebabkan unbalance electric yang mengakibatkan terjadi vibrasi Gambar 16.

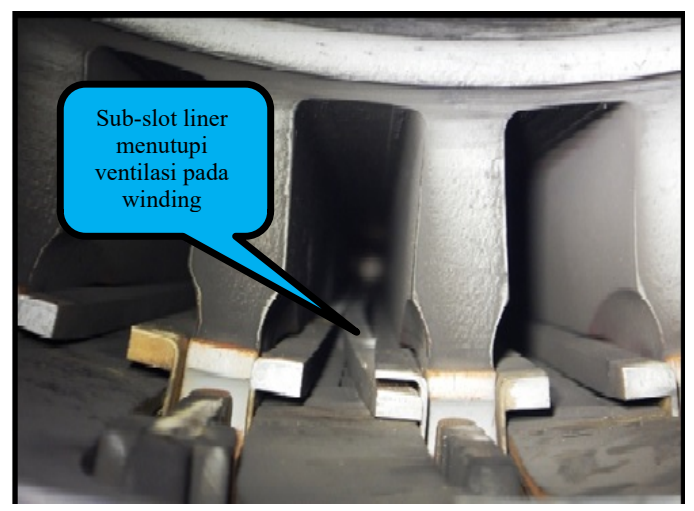

Gambar 16. Sub-slot liner tidak normal.

2. Terjadi kerusakan isolasi pada rotor yang menyebabkan short rotor to ground (hasil pengujian nilai IR melewati batas toleransi standart IEEE 43-2013) Gambar 17.

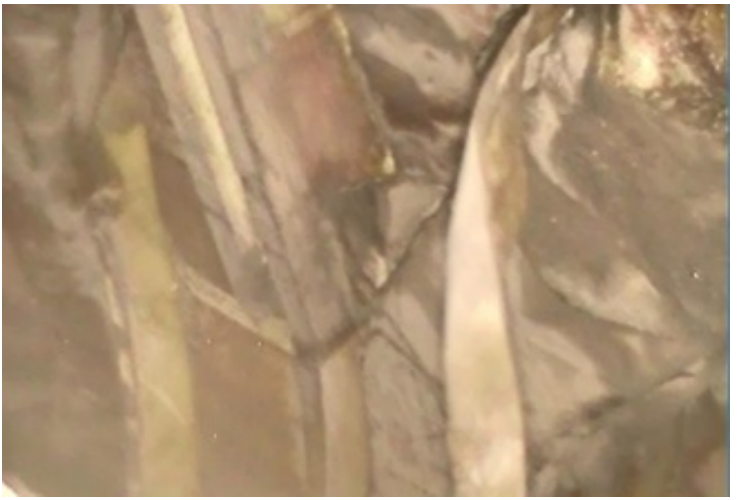

Gambar 17 . Isolasi rusak/tidak normal.

Berikut data hasil pengujian diperoleh nilai yang tidak sesuai standart IEEE 43-2004.Gambar 18.

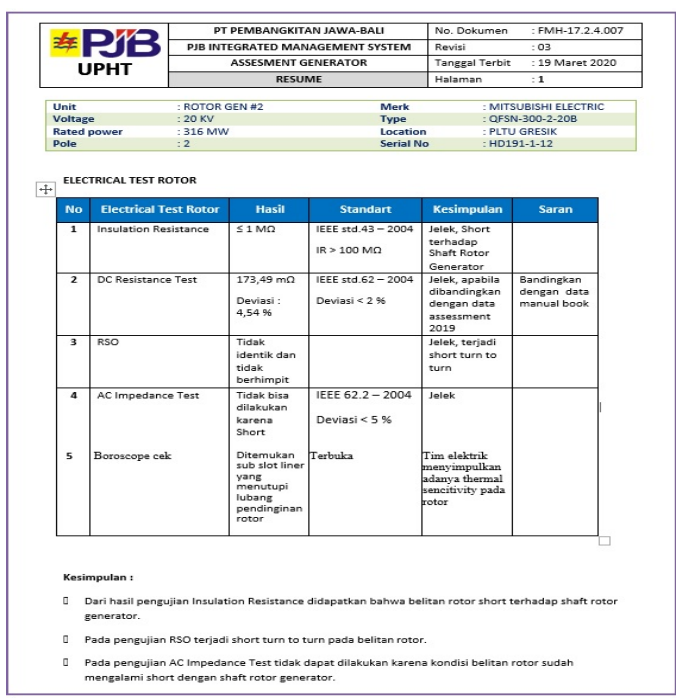

Gambar 18.Hasil pengujian.

Tabel 7.Data Vibrasi setelah Assessment Repair

\begin{tabular}{|c|c|c|c|c|c|c|}
\hline Tag & $\begin{array}{l}\text { G2LA00 } \\
101\end{array}$ & $\begin{array}{l}\text { G2LA002 } \\
64\end{array}$ & $\begin{array}{l}\text { 2MBD1 } \\
\text { 1CY01 } \\
\text { QP }\end{array}$ & $\begin{array}{l}\text { 2MBD12C } \\
\text { Y01QP }\end{array}$ & $\begin{array}{l}\text { 2MKD1 } \\
\text { 1CY01 } \\
\text { QP }\end{array}$ & $\begin{array}{l}\text { 2MKD1 } \\
\text { 2CY01 } \\
\text { QP }\end{array}$ \\
\hline Name & $\begin{array}{l}\text { SPEED } \\
\text { (G2_GI0 } \\
3 \text { ) }\end{array}$ & $\begin{array}{l}\text { ACT LD } \\
\text { (G2_GI03) }\end{array}$ & $\begin{array}{l}\text { BRG } \\
\text { VIB(TR } \\
\text { )1X }\end{array}$ & $\begin{array}{l}\text { BRG } \\
\text { VIB(CM)2 } \\
X\end{array}$ & $\begin{array}{l}\text { GEN } \\
\text { BRG } \\
\text { VIB(TR } \\
\text { ) } 3 \mathrm{X}\end{array}$ & $\begin{array}{l}\text { GEN } \\
\text { BRG } \\
\text { VIB(EC } \\
\text { ) } 4 \mathrm{X}\end{array}$ \\
\hline Unit & RPM & MW & um & um & um & $\mathrm{um}$ \\
\hline $\begin{array}{l}\text { 01/04/2020 } \\
09: 00: 00\end{array}$ & 3000 & 61,1 & 26,8 & 33,5 & 50,1 & 64,2 \\
\hline $\begin{array}{l}01 / 04 / 2020 \\
09: 01: 02\end{array}$ & 3000 & 61,1 & 26,8 & 33,5 & 50,1 & 64,2 \\
\hline $\begin{array}{l}\text { 01/04/2020 } \\
09: 02: 00\end{array}$ & 3004 & 60,6 & 25,8 & 31,3 & 50,1 & 64,2 \\
\hline
\end{tabular}




\section{Kesimpulan}

Dari hasi analisa dan pengujian dapat di simpulkan :

1.Penemuan detail permasalahan dengan beberapa pengujian

1) Dari hasil pengujian Insulation Resistance didapatkan bahwa belitan rotor short terhadap shaft rotor generator.

2) Pada pengujian RSO terjadi short turn to turn pada belitan rotor.

3) Pada pengujian AC Impedance Test tidak dapat dilakukan karena kondisi belitan rotor sudah mengalami short dengan shaft rotor generator.

4) Pada pengecekan boroscope Ditemukan sub slot liner yang menutupi lubang pendinginan rotor sehinga menyebabkan thermal sencitivity pada rotor

\section{Masalah yang diperoleh}

1) Lubang Ventilasi Pendinginan tertutup slot liner sehingga menyebabkan thermal sencitivity pada rotor sehingga terjadi Vibrasi.

2) Kerusakan isolasi rotor menyebabkan Short Turn to Turn yang menyebabkan terjadinya vibrasi.

3.Hasil uji setelah penanganan vibrasi :

1) vibrasi menurun yang awalnya $115 \mu \mathrm{m}$ pada Rpm 3000 menjadi $33.5 \mu \mathrm{m}$ masuk pada standart zona aman yang di izinkan ISO 7919-2.

\section{Ucapan Terimakasih}

Puji syukur kami panjatkan keadirat Allah SWT atas rahmat dan taufiq sertahidayah-nya. Sehinnga penelitian ini dapat terselesaikan.

Dan keberhasilan penelitian ini tidak terlepas dari bantuan berbagai pihak oleh karena itu peneliti ingin gasmenyampaikan rasa terimakasih yang sebesarbesarnya kepada :

1. Rini Puji Astutik, ST,.MT.selaku Dosen pembimbing 1 yang telah memberikan bimbimngan dan petunjuk dengan penuh kesabaran dan setulus hati memberi saran.

2. Deny irawan, ST,.MT selaku Dosen pembimbing 2 yang telah memberikan bimbimngan dan petunjuk dengan penuh kesabaran dan setulus hati memberi saran.
3. Bapak-ibu Dosen Pendidikan Teknik Elektro yang memberikan ilmu selama kuliah

4. PT.PJB UPHT yang bersedia memberikan ijin untuk melakukan penelitian.

5. Kepada orang tua dan saudaraku yang senantiasa memberikan semangan dan motivasi.

\section{Daftar Rujukan}

[1] Enda Permana,1 januari 2012,"Analisa dan solusi penanganan getaran pada turbinpembangkit listrik di PLTP Kamojang unit 1 Darajat", Portal Jurnal Universitas Pendidikan Indonesia.

[2] Eko Setiono,Jefri Syanni edisi 1, 2013, PLN University book 1 Vibration

[3] ISO 10814,2009, Mechanical vibration Susceptibility and sensitivity of machines to unbalance.

[4] IB.P.P.Mahartana dan Harus Laksana Guntur, 2017,Jurnal Teknik ITS Vol 6 No.1. "Pemodelan dan Analisis Pengaruh Kenaikan Putaran Kerja Terhadap Respon Dinamis, Kasus UnbalanceRotor Steam TurbineUnit 1 PLTU Amurang 2x25MW" Laboratorium Vibrasi dan Sistem Dinamis Teknik Mesin, Fakultas Teknologi Industri, Institut Teknologi Sepuluh Nopember (ITS).

[5] Shenglun Zhanga,b, Yu Xingc,a, Hua Xua,b, ^, Shiyuan Peia,b, Lei Zhanga,b, 1 November 2019,Elsevier. "An experimental study on vibration suppression of adjustableelliptical journal bearing-rotor system in various vibrationstates" School of Mechanical Engineering, Xi'an Jiaotong University, Xi'an 710049, Shaanxi, PR China.

[6] Surojit Poddar, N. Tandon, Tribology International 134, 2019, Elsevier. "Detection of particle contamination in journal bearing using acousticemission and vibration monitoring techniques" ITMMEC, Indian Institute of Technology Delhi, New Delhi, 110016, India.

[7] Eko Setiono,Jefri Syanni edisi 1, 2013, PLN University book 2 Vibration

[8] Eko Setiono,Jefri Syanni edisi 1, 2013, PLN University book 3 Vibration

[9] Berry, James E. Copyright 1993; Technical Associates of Charlotte, Inc.; Charlotte, NC.; "Vibration Signature Analysis I".

[10]Steven W.Smith. 1999 by California Technical Publishing;The Scientist and Engineer's Guide to Digital Signal Processing.

[11]ISO 2954:1975, Mechanical Vibration of rotating and reciprocating machinery Requirements for instruments formeasuring Vibration severity.

[12]IHS Licensee Fluor Corporation/2110503105, ISO 108161, 2003 Mechanical vibration Evaluation of machine vibration by measurements on non-rotating parts

[13] Technical Committee ISO/TC 108,2001, ISO 79194, Mechanical vibration Evaluation of machine vibration by measurements on rotating shaft part 4: Gas turbine sets.

[14]Arikunto, Suharsimi. 2010, Prosedur Penelitian Suatu pendekatan Praktek. Jakarta: Rineka Cipta

[15]Jack Peters,2017, Beginning Vibration Analysis With Basic Fundamentals.

[16] Smeisme, A., Saklawi, R., and Yassine, w., 2008, "A Predictive Maintenance Tool: Vibration Analysis to Determine the Condition of Electric Machines", ARISER Vol. 4 No. 3 (2008) 103-117, Electrical and Computer Department, American University of Beirut, LEBANON, 23 June 2008.

[17] Prakash, S., Puri, V, 2006, "Foundation for Vibrating Machines", the Journal of Structural Engineering, SERC, Madras, India April-May

[18] Jayaswal, P, Wadhwani, A., and. Mulchandani, B. Received 29 October 2007; Accepted 21 January 2008 "Machine Fault Signature Analysis".

[19] Oliquino, R., Islam, S., and Eren, H., 2002, "Effects of Types of Faults on Generator Vibration Signatures", School of Electrical and Computer Engineering Curtin University of Technology, Western Australia. [Online]. Available: www.itee.uq.edu.au/ aupec/aupec03/.../008\%200liquino\%20paper.p $\underline{d f}$. 